Karolina S. Prokopović1

Tijana B. Prokopović ${ }^{2}$

Miloje A. Jelić ${ }^{3}$

Niška poslovna škola strukovnih studija, Niš
SCIENTIFIC REVIEW ARTICLE doi:10.5937/ekonomika1601175P

Received: December 16, 2015

Accepted: February 29, 2016

\title{
INFORMATION TECHNOLOGIES IN INTEGRATED LOGISTICS
}

\begin{abstract}
The rapid development of the Internet and the use of new possibilities which the digital technologies have brought about, have made significant changes in all the areas of business, including logistics. The question of whether the advantages of information technology should be used in integrated logistics is no longer posed, rather a new question arises - "How to exploit the advantages of the modern electronic business?". This work attempts at answering this broad \& complex question.

All the subsystems of integrated logistics, such as warehousing, order processing and supply, must be integrated in one unique system via IT. A well established information; system may improve the company's attempts to satisfy the customer's needs, thus improving the aim of the integrated logistics. The practice of successful companies has shown that the elements of integrated logistics, such as low stock levels, just in time delivery, the possibility of replacement of goods depend on timely and accurate flow of information. The application of IT enables faster processing of information, which influences the logistics systems management significantly. Nowadays, the most widely used IT in logistics are: DSS, EDI, barcode technology, RFID. The efficient consumer service policies will soon be inconceivable without the use of these technologies, which is the reason, why they are explored with special attention in this part of the paper. The final part of the paper will show a practical example of the usage of RFID technology for the reduction of fresh food waste in retail.

RFID technology enables the optimization of the entire logistics system, since it monitors the stock continually regardless of whether the products are in the process of manufacturing, distribution center, a retail store or in transport.
\end{abstract}

Keys words: integrated logistics, IT, DSS, EDI, barcode technology, RFID technology.

JEL classificatio: L81, M15

\footnotetext{
${ }^{1}$ prokopovic.karolina@gmail.com

2ticapro89@gmail.com

3 jelic.m@mts.rs
} 


\title{
ИНФОРМАЦИОНИ СИСТЕМИ ИНТЕГРАЛНЕ ЛИГИСТИКЕ
}

\begin{abstract}
Апстракт
Убрзани развој интернета и коришћење нових могућности које пружа дигитална технологија донеле су значајне промене у свим областима пословања па и у логистици. Више се не поставља питање: да ли треба користит предности које пружају информационе технологије у интегралној логистици већ се намеће питање: како најбоље искористит предности савременог електронског пословања? Овај рад је покушај одговора на ово широко и комплексно питање.

Сви подсистеми интегралне логистике као што су складиштење, обрада поруцбине и снабдевање захтевајуповезаност информационим технологијама у један јединствени систем. Добро постављен информациони систем може да помогне предузећу да задовољи потребе потрошача а самим тим олакша мисију интегралне логистике. Пракса успешних предузећа показује да елементи интегралне логистике као што су низак ниво залиха, испорука на време као и могућност замене производа зависи од благовременог и тачног протока информација. Примена информационих технологија омогућава бржу обраду информација која значајно утиче на управљање логистичким системима. Данас су најчешће коришћене информационе технологије у логистичком пословағу: ДСС,ЕДИ, бар код технологија, РФИД технологија. Ефикасна политика услуживања потрошача ће врло брзо бити незамислива без употребе ових технологија, због чега је у овом делу рада юима посвећена посебна пажња. На крају рада приказан је практичан пример примене

РФИД технологије у смањењу пропадања свеже хране у малопродаји. РФИД технологија омогућава оптимизацију целокупног логистичког система јер континуирано прати залихе без обзира да ли се они налазе у производњи, дистрибутивном иентру, малопродајном објекту или можда у транспорту.
\end{abstract}

Кључне речи: интегрална логистика, информационе технологије, ДСС, ЕДИ, бар код технологија, РФИД технологије.

\section{Introduction}

Globalization and technological IT development today are the two main pillars underpinning the modern business enterprise. The explosive development of international trade, harmonization of business conditions in the world, turbulence of the business environment, increasing the number of participants in the markets, only some aspects of the business environment today. In such conditions, decision-making is not at all easy and no longer a matter of routine. Different business decisions are made in order to establish a balance between the potential of the company and demand for its products or services. The adoption of such decisions requires timely and accurate information obtained from the management information system. Logistics information systems can be defined as: 
"Turning people, equipment and procedures that are required to collect, sort, analyze, evaluate, and distribute needed information to appropriate people who make decisions and to timely and accurately so that they can make quality logistics decisions." 4

The definition clearly indicates that the main problem faced by managers of integrated logistics, timely provision of information to decision-making. Otherwise, the logistics information system helps to collect information from various sources, as it is associated with the manufacturing, marketing and financial information systems. Not enough just to have more information, they must be accurate, collected, sorted and delivered to the right people at the right time and in an appropriate form. Information systems are as seen formed and have survived as the necessity of meeting the needs of managers in making right and timely as well as tactical and operational decisions. The significance of information increases with raising the hierarchical levels of decision making. At higher levels of decision-making information used for making strategic decisions, while at lower levels of decision-making information enables operational decisions. Thus, the construction of the logistics information system is one of the key factors to improve the various fields of management integrated logistics.

\section{Principles and functionality of information logistics}

Dispersion and dissemination of technology, as we have seen is changing the way companies operate and the way you communicate with customers and suppliers. In today's dynamic economy, current methods of managing logistics activities are becoming inadequate and managers are forced to innovate the existing methods, and logistics activities such as transportation, warehousing, materials management, purchasing, buying and processing of orders, modernized. If companies ignore these changes and do not meet the requirements of the market at the time, may face a loss in market share and a reduction of competitive advantage. Therefore, great importance attaches to the logistics information system that today is the thread that connects the logistics activities within an integrated road logistics. Functionality and good organization of integrated logistics system based on IT support for all four hierarchical levels of management decision making logistics. Logistical aspects of strategic decision-making involves the development of business capacities, creating business alliances and profit analysis services to consumers.

The second level of distribution logistics information relates to decisions concerning the organization of transport, the determination of the necessary level of inventories, determination of the structure and location of facilities and all decisions of the "make or by".

The third level of information requirements in logistics focuses on the daily activities of management and control as well as financial cost analysis and management of the company.

Last, operational level required logistical information needed to order the entire process from receipt of order to realization.

Functionality distribution logistics information clearly shows that the information requirements of different levels in the decision-making of integrated logistics require

${ }^{4}$ D. Bloomberg, S. LeMay, J. Hanna, Logistics, Prentice Hall, New Yersey, 2006, str. 235. 
differentiation in the logistic information. For example, the strategic level to serve the qualitative aspect of the information while the operational level required quantity. The frequency of the use of information is much more pronounced at a much lower operating at the strategic level. It is also informative width required at the strategic level, while for operational decision-making specialization necessary information. Generally speaking, the information included in the logistics system of the company are different in their content and the main task of the people who are engaged in the organization of physical distribution in the company, so that from a heterogeneous set of information obtained isolate those important for certain levels of logistics management.

All hierarchical needs logistics manager for information should be provided while respecting the basic principles of good logistics of information: ${ }^{5}$

- Accuracy - means the well-organized logistics information system. The essence of the logistics information system is accurate conversion of data into useful information and as such, is directed towards the kind of logistics management to assist in the formulation and adoption of strategic cooperative decisions. Bad data and scant information disturb the logistics activities, but cannot always get to perfect information, either because it cannot be obtained, or because it is too costly.

- Availability - all information must be constantly accessible by enabling information technology. For example, information on stocks and the processing of orders, only some of the information that must be currently available. For the placement of the final products of the utmost importance to the possession of and feedback from the market.

- Elasticity - does the ability to adapt logistics information and readiness of information systems to respond to such demands of its users.

- Up to date - is required in the logistics information system because the weather may be that he does not recognize the new order.

This principle has a direct impact on the fulfillment of the aforementioned principles.

Flexibility and format - is now necessary because customer requirements are very specific, so the system itself must be so designed to quickly and effectively respond and such requirements. Customers can purchase goods from any geographical distance and at any time of day. Flexible system needs all the necessary logistics to format reports and documents at any time and for every need.

It is not easy to develop and organize a good logistics information system because it must respond to the individual needs of the company. For this there is no universal recipe, but personal experiences and needs of businesses are crucial to its development.

\section{Logistics Information systems as a function of processing orders}

Different activities integral logistics must be covered by the logistics information system. Such a system should control all the processes in the physical movement of

${ }^{5}$ Ibid. pp. 193. 
products through the entire distribution process. In fact, the key organization of the logistic system should be the management system for order processing. This system constitutes the connecting link between serving consumers and the logistics information system. Specifically, if the measure of success integral logistics activities competitive and quality level of customer service, then I logistics information system must be functional modern consumer policy service.

The management system of processing orders is generally speaking very complex process. It includes a reception and dissemination of information about the goods commissioned by the customer, then sorting, packing and separation of goods where all accompanied by appropriate documentation. All of these activities are fully in the field of integrated logistics, regardless of whether the company works in the self-directed or uses the services of another company. Modern logistics organization in function of customer service is not possible without the logistics information system itself. This system brings together a series of logistic step in the ordering process.

There are different ways of ordering by customers. The first and oldest method is manual, whether in writing or orally. Most often it is a verbal agreement between the buyer and seller that tracks written confirmation. It is possible to order by phone with the customer will be informed as to whether the required goods in stock. Modern electronic commerce implies a way of ordering the product that best fits in today's logistics information system. Reception of customer orders is carried out its transformation into a logistics information system further checks the state of the stock and credit worthiness of the customer. If the required product is not in stock triggers the process of its procurement. Then form the corresponding document accompanying the goods and sends the signal storage like packaging and separation of goods and transport planning. By specifying the mode of transport, the goods arrive at the place of destination of the buyer.

Order processing system is the center of an integrated logistics system of the company. Efficiently organized, with the help of this system of rapid information flows directly reduces logistics costs for the execution of orders that allow you to maximize the level of customer service while minimizing costs. Fast and accurate information systems are more expensive but it is well organized efficient way to connect with suppliers and customers. On the other hand, the electronic processing of orders organized way to increase sales and profits of the company which has the effect and increase its competitive advantage. An excellent example of the success of the Japanese "just in time" system is a complete organizational and interconnectivity of all flows from production to sales of goods to the end user.

\section{Information technologies in support of information systems, logistics}

Information technologies are now present in all areas of business and enable the transition "from the paper economy" in the virtual reality. Technology, e-business is achieved faster, more accurate and more efficient data exchange, easier and more effective dissemination of information, ie. effective communication between all participants in the e-chain. The time required for the transmission of messages from one end of the world 
on the other, is now measured in seconds. Rapid technological changes affect the area of integrated logistics including the use of laser bar code scanning, integrated circuits, electronic data, satellite data transmission, artificial intelligence, software for warehouse management, etc. Modern managers see the development of logistics information technology as a great opportunity to improve the performance of all logistics activities. All phases of the logistics can be included in the wide application of information technology, which will shorten the time of the exchange of information and thus the completion of orders and this will lead to huge savings in business.

In the sphere of logistics operations now apply many information technologies and some of them will be presented in more detail below:

- Decision Support Systems (DSS);

- Electronic Data Interchange (EDI);

- Bar code system;

- Radio frequency identification (RFID);

- Satellite tracking of vehicles and others.

Solving complex methodological procedures and problems in day to day operations of logistics may speed up and facilitate the application of decision support systems (Decision support systems - DSS). These systems are intended to provide every kind of information support as an input for logistics easier decision-making.

DSS should provide logistics manager in time the information, which will also be accurate, relevant and complete. It must also display information in an appropriate form, to be easy to understand and operate. Information displayed by this system can be the result of internal or can be collected from external sources through the different opinions and forecasts to help a manager. To DSS system was finally able to model through which solves the real problem simplify where appropriate and possible, and that in those aspects that keep his analyzes in detail the real complexity. Decision support systems supporting all phases of decision-making process, starting from the stage of formulation of the problem, through the design phase, selection phase, all the way to its implementation.

Decision support systems provide support for decision-making at all levels of decision-making logistics, or are of special importance to the higher levels. Unlike management information systems, predominantly horizontal facilitate the flow of information, decision support systems supported vertical information flows and so help each other with the integration of the information used at different organizational and managerial levels. So, for example, logistics managers can more easily and quickly decide on the amount of purchases or time when you need to access procurement.

Systems to support decision-making are very efficient but certainly cannot replace managerial decision-making. Can increase the efficiency of decision-making in logistics, and speed in decision making for logistics managers is crucial.

The IT support Integrated Logistics is now widely used electronic exchange of data in a modern way, providing timely and accurate information. Today, electronic data interchange applicable in almost every aspect of integrated logistics, because it allows the flow of documentation i.e. paperless. completely replaces traditional forms of communication by letter, phone or fax. Thus significantly reducing administration, inventory, costs, increases productivity, logistics first and then the whole enterprise. 
Perhaps the greatest benefits of the application of electronic data interchange greater focus on the customer and quickly responding to their needs.

Electronic data affected the way people live and work in all areas, and one of the major impacts is the phenomenon of e-commerce, buying and selling goods and services that erase geographical borders. A large increase was recorded in this area, since the efficiency and effectiveness of logistics key factors of electronic commerce.

There are two basic types of e-commerce: from entrepreneurs to entrepreneurs (B2B - business to business) and from entrepreneurs to customer (B2C - business to customer). Thus, B2B companies interact with each other in many ways, including the purchase of raw materials and services, obtaining information, increasing speed, communication, monitoring, and other products. There are great benefits of B2B commerce and reflected in cost reduction, easier predicting the markets and reducing inventories. But the most attractive is that this mode can make the company more efficient. The second, however, e-commerce category of entrepreneurs to customer (B2C), where trade buyers cooperate with the company over the Internet to obtain goods, services or information. Otherwise, management of integrated logistics in this way for lower purchase costs, faster exchange of information, electronic payment, shorter delivery times and even better service and higher profits. B2C trade advantage is the reduced need for intermediaries. No, however, although the effective use of the Internet can reduce and simplify the supply chain, its complete abolition is not possible because many products require the physical supply chain in order to complete the delivery of the product. The mass of the products are now sold to consumers and a business over the Internet is large and in 2000 amounted to over 2 billion of orders. According to agency reports, the total turnover over the Internet at the global level in 2001 was around 444 billion dollars, while in 2004 reached the incredible sum of 2.7 trillion dollars. These data show that from a logistics system requires high speed and efficiency.

Especially in recent years intensively working on improving electronic commerce with the government. Thus, there are: G2C (government to customer, or a government - users), G2B (government to business or government - entrepreneur) and G2G (government to government, or the government - the government). Those shops are a symbol of the modern state, which applies the principles of modern communication and thus exchanges information with companies, customers, or the governments of other countries.

No matter what type of e-commerce benefits, one thing is certain: it will affect the integral logistics system as a result of e-commerce integrated logistics managers are faced with increasing customer expectations, requirements for quick delivery of products or services and direct communication with buyers. A commercial practice of this kind will still continue to pose a challenge for logistics managers in the future.

The importance of e trade is rapidly growing in the world and talk about the increasing traffic in this market. Thus, for example. Last year on Monday, the first day after the Thanksgiving weekend in the US, called "Cyber Monday" due to the start line on big promotion, the day with the largest on line purchase in history. That day has the highest line on turnover of 1.25 billion dollars. On the same day two years ago, the turnover of one billion dollars. The term "Cyber Monday" has introduced The National Trade Federations in 2005 in order to encourage customers to buy on line Monday, after the big feast. The idea was accepted by the sellers of the day offer great discounts and free delivery, to make as much use on the growing trend of online shopping. 
Social networks have now become an integral part of everyday digital life. Many logistics companies are using this fact to be closer to our clients. For example, the company Timocom believes that Facebook offers an ideal opportunity to connect the business and personal aspects of establishing and relaxed dialogue. Their profile provides pictures from the last fair, the actual video footage and sweepstakes to lure customers freely. Expectations are that the company will communicate with customers in this way, directly and without filtering provide new jobs in different parts of the world.

The leading transport and logistics company in Europe Gebrüder Weiss also uses social networks to attract more customers. They offer logistic game "Logistics Expert", which allows players from beginners to become experts in the logistics puzzle. Puzzle aims to cases, pallets and other goods move to allow the passage of fork-lift trucks carrying cargo. The less you use the player moves, the better the result. With a focus on leisure "Logistics Expert" its directivity to the field of transport and logistics should serve as a form of promotion services company Gebrüder Weiss.

\section{Bar code technology}

It has always been a need to mark items for easy identification. In the beginning, to the participants in the chain provide additional information about goods, items were given general names that became increasingly complex. E-business were the reasons that the goods means and symbols that are recognized machines. Therefore, at the initiative of manufacturers and distributors of 12 European countries formed a council with the task to explore the possibility of a uniform and standard numbering system for Europe. Thus, in 1977. Formed organization numbering items - European Numbering EAN Arctic. The aim of establishing EAN system is the development of global standards for the identification of products and services in order to provide a common language in international trade. Inseparable part of this system is a bar code, as a way of representing data that can be automatically read. This system has quickly become part of information technologies, which has a very important role in the collection and capture the data and their transfer to the computer. Thanks to this system, sales, warehouse and supply logistics provide simultaneous information on the status and trends of each article at any point in time. Bar code system should allow the identification of products that present additional information regarding the date, time, price, specify the manufacturer or importer, and to reduce the amount of stock every item.

An integral part of this system and logistic labels. The purpose of these labels is to provide clear and concise information about the unit in which he adhered. It identifies the items and any additional information required for administrative and logistic purposes. Logistics labels can be affixed to the boxes, crates, pallets and containers, and each of these packages can be composed of homogeneous or heterogeneous products depending on customer requirements. Business partners at different times required information on the identification and movement of these products in order to provide efficient reception, tracking, sorting or repackaging of goods. Therefore it is not modest to say that the advantages of logistic labels especially for the good organization of large integrated logistics:

- As part of the EAN system is compatible with internationally recognized standards 
- It represents a safe solution for logistics systems because it provides one of the most accurate forms of data capture

- Allows you to save time and costs because it reduces errors and helps internal and external integration of logistics operations.

- It only takes one label for all participants in the supply chain. Label manufacturer creates a benefit for everyone in the distribution chain.

- Provided a good link between the physical flow of goods and the flow of electronic information.

Bar code technology allows the optimization of the entire logistics system as it continuously monitors the stocks regardless of whether they are in manufacturing warehouse, distribution center, and retail store or perhaps in transport. Serious policy serving the consumer today is unthinkable without a bar code system that will enable firms not only to be closer to consumers, but also significantly more cost competitive. ${ }^{6}$

\section{RFID Technology}

RFID (Radio Frequency Identification) is a new technology fast automatic identification. It differs from the bar code technology, for data transfer between the reader and the units of goods to be monitored using radio frequency signals instead of optical scanners. RFID is highly efficient wireless technology that is found effective application for tracking goods in the supply chain. RFID tags or labels are placed on objects, boxes or pallets which are monitored throughout the process of distribution and does not require physical contact even have to be in sight of the reader, which significantly accelerates the transport of large quantities of goods.

RFID tag consists of an integrated electrical circuits and memory chips, which are used for storing data and an antenna which can be installed on various types of substrates. RFID systems can read data from tags at a speed of at least 40 tags per second. Size tag can be different, even very small, only a few millimeters depending on the need. In order to achieve the optimum efficiency of each element of the RFID tag is determined according to the specific need. In practice, the most commonly used active and passive tags. Active RFID tags have a battery, which is used to initiate a circuit and a microchip reader to broadcast. Passive tags have no battery. They initiated reader, which sends electromagnetic waves that induce an electrical current in the antenna tag. Semi-passive tags use a battery to run a circuit chip, but communicate by drawing power from the reader. Active and semi-active tags are useful for tracking high-value goods that require to be scanned at large distances, such as the transport of cars on the truck.

There are numerous advantages of this technology compared to bar codes:

- Unlike bar codes RFID tags is virtually impossible to forge.

- $\quad$ RFID technology is very fast. Tag can be read and feedback is available in a very short period of time. RFID systems can also read multiple tags at once (40 tags per second), which is much faster than bar code systems

\footnotetext{
${ }^{6}$ Lisa H. Harrington, Rast, Rirst, Frightened, Supply Chain Technology News 2, no. 1 January 2000., str. 39.
} 
- RFID systems help companies not only improve the technology, but also to lower costs, improve services and reduce the work effort.

- Bar codes and optical systems based on optics and require a relatively clean environment, especially protected from moisture. RFID is ideal for dirty, greasy, damp industrial environment.

- RFID tags and readers have no moving parts, therefore, do not require maintenance. RFID tags can be read into them and can write data that can be far more substantial than other automatic identification technology.

- RFID provides dynamic updating of data on goods that are monitored throughout the haul road in real time.

- With the RFID technology it is possible to remember raw materials, tracking, change from production to end-user supply chain and monitoring packages.

Many companies that have adopted this superior technology, see RFID as a competitive advantage in lowering their costs.

\section{Application of RFID technology in reducing decay Fresh Food retail}

The latest American research institute mijto show that the use of sensors and RFID technology can provide control of fresh fruit and vegetables and thus reduce retail losses due to rotting and throwing rotten food. The new sensors can detect small amounts of ethylene, which shows the maturation of fruits and vegetables. Sensors are attached to the packaging and manually scanned computer can detect maturity fruits and vegetables in the package. In this way, dealers can know what foods to first make available to the purchaser before it loses the freshness so that no one will buy at any price!

According to the US Department of Agriculture, 10\% of fruit and vegetables are thrown in the middle of putrefaction. MIT researchers have tested the sensors in several kinds of fruits and precisely measure their maturity by detecting the amount of ethylene released by the fruit. Since the level of ethylene broadcasts varies from fruit to fruit is very important to distinguish that product is controlled. Major retailers see that huge savings as they may hold inventories to a minimum, it is easier to prevent shrinkage of perishable goods, thus achieving significant cost savings.

In recent years, developing tags the size of a postage stamp that can be placed on meat and fresh meat and radio frequency by sending information on the condition of a dozen sensors to measure temperature, humidity, the number of bacteria, monitor chemical and other changes. These sensors provide the food industry traceability information on the date of production and the origin of food and all for the purpose of consumer safety. Application areas RFID tags can be extended to products in plastic containers, such as juice, milk and other beverages. 


\section{Conclusion}

All the listed information technology represents a very significant support to the functioning of the logistics information system. Their synergistic effect allows for lower costs, increase productivity, accuracy in information, the flexibility of the logistics business as well as support in the strategic analysis. It is certain that each new generation of technology solutions accelerates the process for which it is intended to expand its capacity of work and most importantly, reduce costs. Finally, we summarize the multiple benefits of applying information technology in the integrated logistics:

- E-commerce to sell products directly to consumers, as a result of such sales is to reduce an intermediary in sales while reducing costs, especially storage.

- Information technologies enable customers to order goods at any time, even when the operating time of the retail facility complete.

- E-commerce facilitates the exchange of information in the supply chain, which automatically improves the coordination of its members. Companies offering information on a wide range of its products, and the Internet can be used to obtain information relating to planning and forecasting, which further enhances communication among members of the supply chain. At the same time, the better align supply and demand.

- Companies that do business electronically introduce new products more rapidly, as compared to companies who use traditional methods. The new product is available through a web site as soon as the first units produced. Logistics should be involved in all aspects of new product development, in order to eliminate potential problems, or reduced to a minimum.

In a word, information technology in logistics are a prerequisite to increase competitive advantage and increase the level of customer service, which also represents the main goal of integrated logistics.

\section{Reference}

Acimovic S., Bozic V., (2012), Marketing Logistics, Faculty of Economics, Belgrade. Bloomberg, D. LeMay, S., Hanna, J., (2006), Logistics, Prentice Hall, New Jersey. Barac, N. Milovanovic, G., (2006), Strategic Logistics Management, SKC, Nis.

M. Bitner, Brown Meuter S. \& M. (2000), "Technology in service encounters infusion". Journal of the Academy of Marketing Science 28 (1).

Bloomberg D. LeMay S, Hanna J. (2006), Logistics, Prentice Hall, New Jersey.

Chopra, S. (2004), Supply Chain Management: Strategy, Planning and Operation. Prentice Hall. Englewood Clifs.

Cottrill, K. (2000), "Logistics sold short”. Traffic World. 261(2).

Cullen, T., (2012), "BASF seeks improvement in quality of service firms." Chemical week. no. 162(3)

Jack Farrell W. ,, (2010), “Oranization study: New Clout for Logistics’ Traffic Management, 
Galbraith, J. R (2010). Designing the Global Corporation, Jossey-Bass, San Francisco.

Gligorijević, M. (2004), Industrial marketing. Faculty of Economics, Belgrade, Logistics and transport, newspaper, BEOLOGISTIKA, Novi Sad, br.55-58.

LYSONS, K., (2013), Purchasing and Supply Chain Management. Prentice Hall \& Financial Times.

Clifford F. Lynch (2014), Why outsource ?. Supply Chain Management Review, New York.

Maltz Arnolod B (2004), the Warehousing Function Outsourcing; Economics and Strategic Considerations, Logistics and Transportation 30 (2).

Maricic B. (2003), Consumer Behavior. Faculty of Economics, Belgrade.

P. Robbins, Stephen Coutler Mary, (2005), Menagement, Data status, Belgrade.

Links:

www.gw-world.rs (22.11.2016.)

www.logistika/info.net (22.11.2016.)

www.logistika i transport.com (22.11.2016.)

www.logistikausrbiji.rs (22.11.2016.)

www.logistik.nrw.de (22.11.2016.)

www.storactlog.com (22.11.2016.)

www.timocom.rs (22.11.2016.) 